\title{
Keefektifan pembelajaran berbasis proyek ditinjau dari prestasi belajar, kemampuan berpikir kritis, dan kepercayaan diri siswa
}

\author{
Isnaini Nur Azizah ${ }^{1}$ *, Djamilah Bondan Widjajanti ${ }^{2}$ \\ ${ }^{1}$ SMP Islam Cikal Harapan II. \\ Jl Raya Cileungsi - Jonggol KM 23,2 Sukamaju-Jonggol, Kab. Bogor, Jawa Barat 16830, Indonesia \\ ${ }^{2}$ Universitas Negeri Yogyakarta. Jalan Colombo No. 1, Karangmalang, Yogyakarta 55281, Indonesia. \\ E-mail: isnaininurazizah2015@gmail.com \\ * Corresponding Author
}

\begin{tabular}{|c|c|}
\hline ARTICLE INFO & ABSTRACT \\
\hline $\begin{array}{l}\text { Article history } \\
\text { Received: } 25 \text { Sept. 2017; } \\
\text { Revised: } 12 \text { Nov. } 2019 ; \\
\text { Accepted: } 30 \text { Nov. } 2019 \\
\text { Keywords } \\
\text { pembelajaran berbasis } \\
\text { proyek; prestasi belajar; } \\
\text { kemampuan berpikir kritis; } \\
\text { kepercayaan diri; project- } \\
\text { based learning; learning } \\
\text { achievement; critical } \\
\text { thinking skill; self- } \\
\text { confidence }\end{array}$ & $\begin{array}{l}\text { Tujuan penelitian ini untuk mendeskripsikan keefektifan pembelajaran berbasis } \\
\text { proyek pada materi statistika ditinjau dari prestasi belajar, kemampuan berpikir } \\
\text { kritis, dan kepercayaan diri siswa SMP kelas VII. Pembelajaran berbasis proyek } \\
\text { terdiri dari enam langkah yaitu: (1) penentuan proyek; (2) perancangan lang- } \\
\text { kah-langkah penyelesaian proyek; (3) penyusunan jadwal pelaksanaan proyek; } \\
\text { (4) penyelesaian proyek dengan fasilitasi dan monitoring guru; (5) penyusunan } \\
\text { laporan dan presentasi/publikasi hasil proyek; dan (6) evaluasi dan hasil proyek. } \\
\text { Populasi dalam penelitian ini adalah siswa kelas VII SMP Negeri } 1 \text { Yogyakarta. } \\
\text { Instrumen yang digunakan adalah tes prestasi belajar, tes kemampuan berpikir } \\
\text { kritis, angket kepercayaan diri, dan lembar observasi keterlaksanaan pembel- } \\
\text { ajaran. Uji hipotesis menggunakan uji proporsi } Z \text { pada taraf signifikan } 95 \% \text { ( } \\
=5 \% \text { ). Berdasarkan hasil uji hipotesis diperoleh proporsi siswa yang prestasi } \\
\text { belajarnya telah mencapai KKM lebih dari 75\%. Proporsi siswa yang memiliki } \\
\text { kemampuan berpikir kritis dan kepercayaan diri pada kategori minimal "baik" } \\
\text { lebih dari } 75 \% \text {. Dengan demikian dapat disimpulkan bahwa pembelajaran } \\
\text { berbasis proyek efektif ditinjau dari prestasi belajar, kemampuan berpikir kritis, } \\
\text { dan kepercayaan diri siswa. }\end{array}$ \\
\hline
\end{tabular}

The purpose of this study was to describe the effectiveness of project-based learning in statistical material viewed from learning achievement, critical thinking skills, and self-confidence of seventh-grade junior high school students. Project-based learning consists of six steps: (1) determining the project; (2) designing project completion steps; (3) preparing the project implementation schedule; (4) completion of the project with facilitation and monitoring from the teacher; (5) preparation of reports and presentation/ publication of project results; and (6) evaluation and results of the project. The population in this study was seventh-grade students of SMP 1 Yogyakarta, Indonesia. The instruments used were a learning achievement test, a critical thinking ability test, a self-confidence questionnaire, and an observation sheet of learning accomplishments. Hypothesis testing uses the proportion $Z$ test at a significant level of $95 \%(\alpha=5 \%)$. Based on the results of the hypothesis test, the proportion of students who have learning achievement reached KKM was more than $75 \%$. The proportion of students who have critical thinking skills and selfconfidence in the minimum category of "good" was more than 75\%. Thus it could be concluded that project-based learning was an effective view from students' learning achievement, critical thinking skills, and self-confidence.

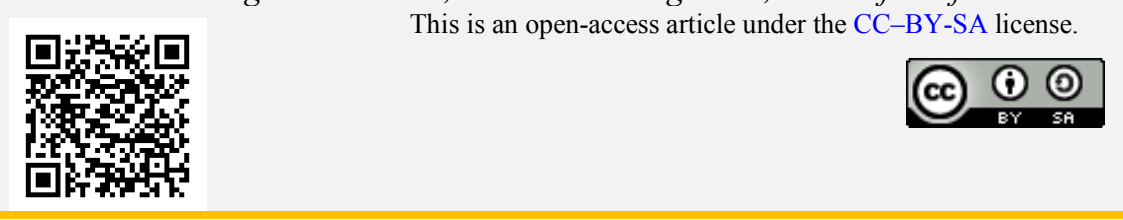

How to Cite: Azizah, I., \& Widjajanti, D. (2019). Keefektifan pembelajaran berbasis proyek ditinjau dari prestasi belajar, kemampuan berpikir kritis, dan kepercayaan diri siswa. Jurnal Riset Pendidikan Matematika, 6(2), 233243. doi:https://doi.org/10.21831/jrpm.v6i2.15927 


\section{PENDAHULUAN}

Pendidikan merupakan salah satu aspek penting untuk membangun sumber daya manusia yang berkualitas yang siap menghadapi perubahan zaman. Berbicara mengenai pendidikan tentunya sangat berkaitan erat dengan kurikulum. Kurikulum merupakan inti utama dalam sebuah pendidikan yang berperan untuk mewujudkan tujuan pendidikan. Saat ini kurikulum yang digunakan di Indonesia adalah Kurikulum 2013 edisi revisi yang merupakan perubahan dari kurikulum sebelumnya. Hal yang mendasari adanya perubahan kurikulum yaitu selain sebagai penyempurnaan kurikulum sebelumnya, juga untuk memperbaiki capaian kompetensi siswa yang disesuai dengan kebutuhan zaman.

Undang-Undang Republik Indonesia nomor 20 tahun 2003 tentang sistem pendidikan nasional (2003) menjelaskan bahwa untuk mewujudkan tujuan pendidikan nasional diperlukan profil kualifikasi kemampuan lulusan yang tertuang dalam standar kompetensi lulusan. Standar kompetensi lulusan tersebut di antaranya mencakup aspek sikap, pengetahuan, dan keterampilan. Hal senada dijelaskan pula oleh Hosnan dan Sikumbang (2014) bahwa kompetensi kegiatan dalam Kurikulum 2013 adalah untuk memberdayakan potensi-potensi yang dimiliki peserta didik melalui upaya menumbuhkan serta mengembangkan sikap (attitude), pengetahuan (knowledge), dan keterampilan (skill). Hal demikian dikarenakan, pengembangan antara ranah kompetensi yang satu dengan yang lainnya tidak bisa dipisahkan, sehingga proses pembelajaran dapat dengan utuh melahirkan kualitas pribadi siswa baik sikap, pengetahuan, maupun keterampilan (Peraturan Menteri Pendidikan dan Kebudayaan Nomor 22 tahun 2016 tentang standar proses pendidikan dasar dan menengah, 2016).

Kompetensi siswa yang mencakup aspek sikap, pengetahuan, dan keterampilan menjadi ukuran perkembangan dan kemajuan siswa selama pembelajaran. Hal tersebut tercermin dalam prestasi belajar siswa. Prestasi belajar merupakan hal terpenting bagi siswa serta hasil usaha siswa selama proses pembelajaran. Prestasi belajar dipahami sebagai suatu keberhasilan atau kemajuan akademik siswa berupa pengetahuan, keterampilan dan kemampuan sebagai hasil dari sebuah pengajaran di sekolah yang biasanya diukur dengan penilaian kelas, penilaian di ruang kelas, dan tes prestasi (Arends \& Kilcher, 2010; Garber, 2009; Keller et al., 2017; Kpolovie et al., 2014; Merilia et al., 2019; Miller et al., 2008; Nitko \& Brookhart, 2011).

Ada beberapa kendala yang hingga kini masih hangat diperbincangkan khususnya di bidang pendidikan adalah masih rendahnya prestasi belajar siswa terutama untuk mata pelajaran matematika. Rendahnya prestasi belajar siswa dapat dilihat berdasarkan hasil Ujian Nasional (UN) yang dijadikan tolak ukur dalam mengukur keberhasilan belajar siswa. Provinsi Daerah Istimewa Yogyakarta merupakan provinsi dengan indeks prestasi yang cukup baik, namun berdasarkan laporan hasil UN untuk provinsi tersebut pada jenjang SMP/MTs ternyata rata-rata hasil UN matematika cenderung mengalami penurunan. Berikut data hasil UN jenjang SMP/MTs selama empat tahun terakhir untuk tingkat nasional dan Provinsi Daerah Istimewa Yogyakarta yang ditunjukkan pada Tabel 1.

Tabel 1. Laporan Hasil UN Matematika SMP/MTs

\begin{tabular}{ccc}
\hline Tahun Pelajaran & Nasional & D.I. Yogyakarta \\
\hline $2012 / 2013$ & 57,80 & 61,20 \\
$2013 / 2014$ & 61,00 & 61,10 \\
$2014 / 2015$ & 56,28 & 58,66 \\
$2015 / 2016$ & 50,24 & 55,71 \\
\hline
\end{tabular}

Sumber: Badan Penelitian dan Pengembangan (2013, 2014, 2015, 2016)

Berdasarkan hasil UN matematika SMP (lihat Tabel 1), nilai rata-rata hasil UN matematika pada tingkat nasional mengalami penurunan dari tahun 2015 ke 2016 yaitu dari 56,28 menjadi 50,24. Hasil UN untuk wilayah Provinsi DIY telah mengalami penurunan sejak tahun 2013 hingga tahun 2016, yaitu dari 61,20 menjadi 55,71. Hal ini menjadi sorotan utama bahwa prestasi belajar matematika siswa perlu ditingkatkan lagi.

Prestasi belajar siswa SMP/MTs dapat dilihat pula berdasarkan daya serap materi matematika. Dari lima konten matematika yang diujikan yakni Bilangan, Aljabar, Geometri, Pengukuran, serta Statistika dan Peluang, materi statistika memiliki persentase daya serap yang paling tinggi yaitu sebesar 74,22 pada tahun pelajaran 2012/2013 dibandingkan dengan materi lainnya, namun pada tahun berikutnya materi tersebut mengalami penurunan rata-rata, dan rata-rata paling rendah terdapat pada tahun 2015/2016 untuk tingkat nasional yaitu sebesar 46,73 (Badan Penelitian dan Pengembangan, 2013, 
2014, 2016). Dengan memperhatikan tinjauan data tersebut, maka penelitian ini difokuskan pada materi statistika.

Pemberian mata pelajaran matematika, selain agar peserta didik memiliki prestasi belajar yang baik, juga bertujuan agar siswa memiliki kemampuan berpikir tingkat tinggi. Hal tersebut dijelaskan Peraturan Menteri Pendidikan Nasional Republik Indonesia Nomor 22 Tahun 2006 tentang standar isi untuk satuan pendidikan dasar dan menengah (2006) yang menyatakan bahwa mata pelajaran matematika perlu diberikan kepada semua peserta didik mulai dari sekolah dasar untuk membekali peserta didik dengan kemampuan berpikir logis, berpikir analitis, berpikir sistematis, berpikir kritis, dan berpikir kreatif, serta kemampuan bekerja sama. Salah satu kemampuan berpikir tingkat tinggi yang harus dimiliki siswa dalam pembelajaran matematika adalah kemampuan berpikir kritis. Kemampuan berpikir kritis merupakan kemampuan siswa dalam mengidentifikasi, menganalisis, mengevaluasi dan menyimpulkan (Arends \& Kilcher, 2010; Duron et al., 2006; Fisher, 2001; Moore, 2014; Paul \& Elder, 2019).

Pentingnya siswa berpikir kritis adalah agar siswa di setiap menghadapi masalah terlatih untuk menyelesaikannya dengan cara berpikir kritis. Pentingnya berpikir kritis juga dijelaskan oleh CasnerLotto dan Barrington (2006, p. 9) dalam surveinya mengenai kebutuhan dunia kerja di Amerika Serikat bahwa hal yang sangat penting dan berada pada urutan pertama untuk sukses di dunia kerja adalah berpikir kritis. Ini dapat menjadi pandangan bagi dunia pendidikan apa yang dibutuhkan oleh peserta didik di masa yang akan datang yakni kemampuan berpikir kritis. Oleh karena itu, dibutuhkan pengajaran yang melibatkan pemikiran kritis, konten menarik, kesempatan untuk mempraktikkannya, dan penilaian terhadap usaha mereka dalam berpikir kritis (Lang \& Evans, 2006, p. 460).

Hal senada juga dikemukakan oleh Chrissanti dan Widjajanti $(2015$, p. 52) bahwa kemampuan berpikir kritis peserta didik dapat dikembangkan melalui pembelajaran yang melibatkan para peserta didik secara aktif dan guru harus mampu memberikan pembelajaran yang melibatkan para peserta didik aktif dalam mengonstruksi pengetahuannya. Pembelajaran yang mendukung berpikir kritis menggunakan teknik tanya jawab yang mengharuskan siswa menganalisis, mensintesis, dan mengevaluasi informasi untuk memecahkan masalah dan membuat keputusan, bukan sekadar mengulang informasi (menghafal). Selain itu untuk menghubungkan kemampuan berpikir kritis dengan materi, fokus pembelajaran harus pada proses belajar (Peter, 2012, p. 40).

Fakta yang terjadi di lapangan menunjukkan masih kurangnya pembelajaran siswa yang berorientasi kepada kemampuan berpikir kritis. Rendahnya kemampuan berpikir kritis siswa juga dapat dilihat dari hasil laporan PISA (Programme for International Student Assesment) pada tahun 2009. Pada laporan tersebut, sebagian besar siswa Indonesia masih di bawah tingkat 2 pada usia 15 tahun. Sedangkan untuk negara Australia, Finlandia, Hong Kong dan Jepang sudah berada pada level 5 dan 6 . Berdasarkan OECD 2010, level 2 mewakili tingkat dasar kemampuan matematika dalam skala PISA dimana siswa mulai menunjukkan jenis keterampilan yang memungkinkan mereka menggunakan matematika dengan cara yang dianggap mendasar (Stacey, 2011, p. 108).

Acuan dalam penggunaan data PISA ini dikarenakan konsep literasi dalam PISA berkaitan dengan kompetensi siswa dalam menganalisis, menalar, dan berkomunikasi. Menganalisis dan menalar merupakan kemampuan yang digunakan siswa untuk berpikir kritis. Selain itu, Stacey (2011, p. 103) berpendapat bahwa literasi matematika tidak hanya menggambarkan kemampuan matematika tingkat dasar yang digunakan dalam aktivitas matematika sederhana, tetapi juga kemampuan menggunakan matematika pada tingkat kesulitan yang lebih tinggi. Oleh karena itu, literasi matematika tidak hanya mencakup kemampuan berpikir tingkat rendah, tetapi juga kemampuan berpikir tingkat tinggi. Dengan demikian, kemampuan siswa dalam berpikir tingkat tinggi terutama berpikir kritis masih sangat perlu mendapat perhatian.

Selain data tersebut, peneliti juga melakukan pra-penelitian pada siswa kelas VII di salah satu SMP negeri di Kota Yogyakarta. Peneliti memberikan satu butir soal kemampuan berpikir kritis pada aspek menganalisis dengan indikator mengidentifikasi informasi yang perlu (poin a) dan mencari hubungan antar informasi (poin b). Berdasarkan hasil pra-penelitian tersebut, ditemukan bahwa dari 15 siswa yang mengerjakan soal tersebut, hanya sebanyak 5 siswa yang benar menjawab poin a, dan untuk poin b sebanyak 4 siswa yang menjawab benar.

Hasil pra-penelitian tersebut dapat menjadi salah satu indikasi bahwa masih perlu ditingkatkannya kemampuan siswa dalam berpikir kritis. Seperti yang diungkapkan oleh Rosnawati $(2009$, p.509) bahwa matematika berkaitan erat dengan logika, namun untuk mengembangkan kemampuan berpikir kritis dibutuhkan keterampilan berpikir yang bukan hanya sekedar menghafal rumus, menemukan rumus 
tanpa mengetahui kaitan satu dengan yang lainnya, atau menyelesaikan soal secara mekanik, tanpa melibatkan keterampilan berpikir. Dengan demikian, untuk mengembangkan kemampuan berpikir kritis juga harus diiringi dengan pemberdayaan aspek-aspek yang ada pada diri siswa, termasuk aspek sikap (afektif).

Di samping aspek kognitif, aspek afektif siswa juga memiliki peranan yang penting di dalam pembelajaran, seperti kepercayaan diri siswa (Rahmadhani, 2018; Ramadhani, 2018). Kepercayaan diri merupakan keyakinan akan kemampuan diri seseorang untuk mencapai segala sesuatu/tujuan yang diinginkan serta memiliki sikap optimis dan bertanggung jawab (Ghufron \& Suminta, 2010; Preston, 2005; Schunk, 2012; Singh \& Kaur, 2008). Namun berdasarkan fakta yang ada, untuk menumbuhkan rasa percaya diri pada setiap siswa tidaklah mudah. Masih terdapat siswa yang memiliki rasa percaya diri yang rendah, hal ini terlihat dari hasil pra-penelitian terhadap angket kepercayaan diri yang dilakukan peneliti di kelas VII salah satu SMP negeri di Kota Yogyakarta bahwa sebesar 41,94\% (13 siswa) berada pada kategori rendah, 29,03\% (9 siswa) pada kategori sedang, 19,35\% (6 siswa) pada kategori tinggi, dan 9,68\% (3 siswa) pada kategori sangat tinggi.

Selain dari angket yang diberikan, peneliti juga melakukan observasi kelas. Berdasarkan hasil observasi diketahui pula bahwa faktor lain yang mempengaruhi kepercayaan diri siswa adalah (1) siswa kurang percaya diri ketika diberi tugas yang mengharuskan siswa mempresentasikan hasilnya di depan kelas, (2) ketika diberi tugas yang sulit, siswa masih enggan untuk bertanya kepada guru, (3) siswa masih kurang percaya diri terhadap tugas yang telah dikerjakannya, (4) siswa perlu didorong dengan kegiatan yang memicu siswa untuk aktif di dalam kelas, hal tersebut terlihat pada saat guru memberi stimulus yang merangsang siswa untuk melakukan kegiatan, siswa baru bertindak, apabila guru tidak menstimulus siswa dengan kegiatan yang membuat siswa aktif seperti bertanya atau mengemukakan pendapat maka siswa tidak akan bertanya atau mengemukakan pendapat. Tentu saja dengan masih adanya perbedaan kepercayaan diri antara siswa yang satu dengan lainnya mengakibatkan perolehan prestasi yang dicapai siswa pun berbeda-beda.

Berkaca dari masih rendahnya prestasi belajar siswa, kemampuan berpikir kritis, dan kepercayaan diri siswa, ini menjadi acuan bagi pendidik bahwa proses pembelajaran yang saat ini digunakan perlu mendapat perhatian khusus. Guru harus lebih bijak dalam menentukan sebuah metode atau model pembelajaran yang tepat dalam pembelajaran, sehingga proses pembelajaran akan menjadi lebih efektif. Hal ini sesuai dengan pendapat Popham dan Baker (Hosnan \& Sikumbang, 2014) bahwa proses belajar mengajar yang efektif sangat tergantung pada pemilihan dan penggunaan metode pembelajaran untuk dapat memaksimalkan pembelajaran yang efektif.

Salah satu model pembelajaran yang dapat mewadahi siswa pada prestasi belajar, kemampuan berpikir kritis, serta dapat mengembangkan kepercayaan diri siswa yaitu pembelajaran berbasis proyek. Pembelajaran berbasis proyek adalah model pembelajaran dengan kegiatan proyek (Thomas, 2000). Secara umum langkah-langkah kegiatan pembelajaran berbasis proyek yaitu: (1) penentuan proyek; (2) perancangan langkah-langkah penyelesaian proyek; (3) penyusunan jadwal pelaksanaan proyek; (4) penyelesaian proyek dengan fasilitasi dan monitoring guru; (5) penyusunan laporan dan presentasi/ publikasi hasil proyek; (6) evaluasi proyek dan hasil proyek (Hosnan \& Sikumbang, 2014).

Menurut Bender (2012) dalam melakukan proyek, siswa di kelas dapat dibagi menjadi dua atau tiga tim dengan masing-masing tim bertanggung jawab untuk menangani keseluruhan masalah serta menghasilkan benda-benda yang dibutuhkan untuk menyelesaikan proyek. Tujuan utama dari kelompok proyek adalah sebagai teknik penilaian untuk mengevaluasi apakah siswa dapat bekerja sama secara kooperatif dan tepat untuk menciptakan produk yang berkualitas tinggi (Nitko \& Brookhart, 2011).

Pembelajaran berbasis proyek tidak hanya melibatkan siswa secara aktif dalam mengembangkan proses berpikir tetapi juga melibatkan siswa untuk belajar secara langsung. Hal ini dijelaskan pula oleh Tim Pengembang MKDP Kurikulum dan Pembelajaran (2011) bahwa pendekatan pembelajaran yang mampu melibatkan siswa secara langsung aktif akan menghasilkan pembelajaran lebih efektif dibandingkan dengan pendekatan yang hanya sekedar menuangkan pengetahuan-pengetahuan informasi. Siswa dapat mengonstruksi dan membangun pengetahuan mereka sendiri serta menyimpan lebih banyak informasi ketika mereka belajar dengan melakukan (Bell, 2010).

Penelitian terkait pembelajaran berbasis proyek, sebelumnya telah banyak dilakukan. Penelitian yang dilakukan oleh Imawan (2015) menunjukkan bahwa model pembelajaran berbasis proyek efektif ditinjau dari prestasi belajar, kemampuan berpikir kritis, dan kepercayaan diri. Penelitian tersebut menggunakan mahasiswa sebagai subjek penelitian. Ismail (2018) meneliti keefektifan model pembelajaran 
berbasis proyek dan model pembelajaran berbasis masalah pada materi pokok bangun ruang sisi datar di SMP ditinjau dari ketercapaian tujuan pembelajaran siswa. Penelitian ini mengukur ketercapaian tujuan pembelajaran berupa keterampilan pemecahan masalah dan kepercayaan diri. Adapun hasil yang diperoleh dari penelitian ini adalah bahwa model pembelajaran berbasis proyek efektif ditinjau dari percaya diri dan keterampilan pemecahan masalah.

Peneliti ingin mencoba menerapkan pembelajaran berbasis proyek pada tingkat yang lebih rendah yaitu tingkat SMP. Hal ini didasarkan pada pendapat Klein et al. $(2009$, p. 8) bahwa pembelajaran berbasis proyek juga relevan untuk siswa sekolah menengah, hal ini dikarenakan sekolah menengah adalah waktu yang ideal untuk mengintegrasikan pembelajaran berbasis proyek. Dari pemaparan tersebut, maka penelitian ini bertujuan untuk mendeskripsikan keefektifan pembelajaran berbasis proyek ditinjau dari prestasi belajar, kemampuan berpikir kritis, dan kepercayaan diri siswa SMP.

\section{METODE}

Penelitian ini dilaksanakan mulai dari tanggal 28 Maret 2017 hingga 13 Mei 2017 di SMP Negeri 1 Yogyakarta. Populasi pada penelitian ini adalah siswa kelas VII SMP Negeri 1 Yogyakarta yang terdiri dari 8 kelas. Kedelapan kelas tersebut memiliki prestasi akademik relatif setara dan tidak ada kelas yang berstatus unggulan. Sampel penelitian adalah siswa kelas VII H pada tahun ajaran 2016/2017 yang dipilih secara acak. Kelas tersebut terdiri dari 34 siswa dengan kemampuan akademik beragam.

Teknik pengumpulan data yang digunakan adalah teknik tes dan non tes. Tes digunakan untuk mengukur prestasi belajar dan kemampuan berpikir kritis siswa. Kemudian non tes digunakan untuk mengukur kepercayaan diri siswa, menilai perangkat pembelajaran dan instrumen yang disusun, dan mengetahui keterlaksanaan pembelajaran. Instrumen pengumpulan data pada penelitian ini terdiri dari soal prestasi belajar, soal kemampuan berpikir kritis, angket kepercayaan diri siswa, dan lembar observasi keterlaksanaan pembelajaran.

Berdasarkan hasil penilaian para ahli, perangkat pembelajaran dan instrumen yang disusun telah memenuhi kriteria valid dan layak digunakan dalam proses pembelajaran. Sebelum digunakan dalam proses pembelajaran, dilakukan estimasi reliabilitas instrumen. Instrumen dinyatakan reliabel jika minimum nilai estimasi reliabilitas yang diperoleh sebesar 0,65 (Ebel \& Frisbie, 1991, p. 86). Hasil reliabilitas instrumen disajikan pada Tabel 2. Berdasarkan hasil estimasi reliabilitas pada Tabel 2, ketiga instrumen tersebut dinyatakan reliabel.

Tabel 2. Estimasi Reliabilitas Instrumen Penelitian

\begin{tabular}{|c|c|}
\hline Instrumen & Reliabilitas \\
\hline Tes Prestasi Belajar & 0,693 \\
\hline Tes Kemampuan Berpikir Kritis & 0,680 \\
\hline Angket kepercayaan diri & 0,900 \\
\hline
\end{tabular}

Teknik analisis data yang digunakan adalah uji normalitas dan uji hipotesis. Uji normalitas bertujuan untuk mengetahui apakah data berasal dari populasi yang berdistribusi normal atau tidak. Uji hipotesis bertujuan untuk mengetahui keefektifan pembelajaran berbasis proyek ditinjau dari prestasi belajar, kemampuan berpikir kritis, dan kepercayaan diri siswa. Pembelajaran berbasis proyek dikatakan efektif jika proporsi siswa yang telah mencapai KKM lebih dari $75 \%$, proporsi siswa yang telah mencapai skor kemampuan berpikir kritis pada kategori minimal baik lebih dari $75 \%$, dan proporsi siswa yang telah mencapai skor kepercayaan diri pada kategori minimal baik lebih dari $75 \%$. Pengujian statistik dilakukan pada taraf signifikan $\alpha=5 \%$ dan statistik uji seperti pada Persamaan Rumus 1.

$Z=\frac{x / n-\pi_{0}}{\sqrt{\pi_{0} q_{0} / n}}$

dimana $x$ merupakan jumlah siswa yang mencapai kriteria yang ditetapkan, $\pi_{0}$ merupakan proporsi sampel yang dihipotesiskan, $q_{0}=1-\pi_{0}$, dan $n$ merupakan banyak siswa.

\section{HASIL DAN PEMBAHASAN}

Sebelum dilakukan pengujian hipotesis, terlebih dahulu dilakukan uji normalitas. Uji normalitas bertujuan untuk mengetahui apakah data berasal dari populasi yang berdistribusi normal atau tidak, dengan hipotesis sebagai berikut. 
$H_{0}$ : data berasal dari populasi yang berdistribusi normal

$H_{1}$ : data berasal dari populasi yang tidak berdistribusi normal

Pengujian hipotesis dilakukan menggunakan uji One-sample Kolmogorov-Smirnov Z test. Kriteria keputusan adalah $H_{0}$ diterima apabila signifikansi lebih dari $\alpha(5 \%)$. Hasil uji normalitas disajikan pada Tabel 3.

Tabel 3. Hasil Uji Normalitas Instrumen

\begin{tabular}{lc}
\hline Instrumen & Sig. (2-tailed) \\
\hline Soal Prestasi Belajar & 0,322 \\
Soal Kemampuan Berpikir Kritis & 0,546 \\
Angket Kepercayaan diri & 0,812 \\
\hline
\end{tabular}

Berdasarkan hasil data pada Tabel 3, diperoleh nilai signifikansi data untuk setiap instrumen lebih dari $\alpha=0,05$. Dari hasil yang diperoleh, dapat disimpulkan bahwa data berasal dari populasi yang berdistribusi normal.

Selanjutnya dilakukan uji hipotesis yang bertujuan untuk mengetahui keefektifan pembelajaran berbasis proyek ditinjau dari prestasi belajar, kemampuan berpikir kritis, dan kepercayaan diri. Tes prestasi belajar matematika diberikan kepada siswa kelas VII H SMP Negeri 1 Yogyakarta. Adapun secara ringkas rekapitulasi hasil tes prestasi belajar siswa disajikan pada Tabel 4.

Tabel 4. Hasil Tes Prestasi Belajar

\begin{tabular}{lc}
\hline Deskripsi & Nilai \\
\hline Jumlah siswa & 34 \\
Nilai tertinggi & 100 \\
Nilai terendah & 40 \\
Siswa tuntas & 30 \\
Siswa tidak tuntas & 4 \\
Persentase ketuntasan & $88.24 \%$ \\
\hline
\end{tabular}

Berdasarkan data yang ada, dilakukan uji hipotesis menggunakan uji proporsi $Z$. Pembelajaran berbasis proyek dikatakan efektif jika proporsi siswa yang mencapai KKM lebih dari $75 \%$. Adapun hipotesis yang digunakan sebagai berikut.

$H_{0}: \pi \leq 75 \%$, Proporsi siswa yang telah mencapai KKM kurang dari atau sama dengan $75 \%$.

$H_{1}: \pi>75 \%$, Proporsi siswa yang telah mencapai KKM lebih dari $75 \%$.

Dari data sampel diperoleh $Z=1,782$ dan karena $Z_{0,05}=1,645$, hal ini berarti $Z>Z_{\alpha}$, dengan demikian $H_{O}$ ditolak dan $H_{1}$ diterima. Dapat disimpulkan bahwa proporsi siswa yang telah mencapai KKM lebih dari 75\%. Berdasarkan kriteria keefektifan yang telah dirancang, maka pembelajaran berbasis proyek dinyatakan efektif ditinjau dari prestasi belajar matematika.

Kemudian hasil tes kemampuan berpikir kritis juga menjadi penentu kriteria keefektifan pelaksanaan pembelajaran yang telah dibuat. Secara ringkas rekapitulasi hasil tes kemampuan berpikir kritis matematika siswa disajikan pada Tabel 5.

Tabel 5. Hasil Tes Kemampuan Berpikir Kritis

\begin{tabular}{lc}
\hline Keterangan & Angka \\
\hline Jumlah siswa & 34 \\
Nilai tertinggi & 36 \\
Nilai terendah & 18 \\
Siswa tuntas & 31 \\
Siswa tidak tuntas & 3 \\
Persentase ketuntasan & $91.18 \%$ \\
\hline
\end{tabular}

Pembelajaran berbasis proyek dikatakan efektif jika proporsi siswa yang telah mencapai skor kemampuan berpikir kritis pada kategori minimal baik lebih dari 75\%, dengan hipotesis sebagai berikut. $H_{0}: \pi \leq 75 \%$, Proporsi siswa yang telah mencapai skor kemampuan berpikir kritis pada kategori minimal baik kurang dari atau sama dengan $75 \%$.

$H_{1}: \pi>75 \%$, Proporsi siswa yang telah mencapai skor kemampuan berpikir kritis pada kategori minimal baik lebih dari $75 \%$. 
Dari data sampel diperoleh $Z=2,178$ dan karena $Z_{0,05}=1,645$, hal ini berarti $Z>Z_{\alpha}$, dengan demikian $H_{o}$ ditolak dan $H_{1}$ diterima. Dapat disimpulkan bahwa proporsi siswa yang telah mencapai skor kemampuan berpikir kritis pada kategori minimal baik lebih dari $75 \%$. Berdasarkan kriteria keefektifan yang telah dirancang, pembelajaran berbasis proyek efektif ditinjau dari kemampuan berpikir kritis.

Penilaian keefektifan juga diperoleh dari hasil angket kepercayaan diri siswa yang diberikan pada awal dan akhir pembelajaran. Adapun hasil dari angket kepercayaan diri siswa disajikan pada Tabel 6.

Tabel 6. Hasil Angket Kepercayaan Diri

\begin{tabular}{lcc}
\hline & \multirow{2}{*}{ Kategori } & \multicolumn{2}{c}{ Jumlah siswa } \\
\cline { 2 - 3 } & Awal & Akhir \\
\hline Sangat baik & 0 & 10 \\
Baik & 8 & 21 \\
Cukup & 23 & 3 \\
Kurang & 3 & 0 \\
Sangat kurang & 0 & 0 \\
\hline dang
\end{tabular}

data yang ada, terlebih dilakukan uji untuk mengetahui apakah rata-rata skor angket akhir lebih dari rata-rata skor angket awal, dengan hipotesis sebagai berikut.

$H_{0}: \mu_{b} \leq \mu_{a}$, Rata-rata skor kepercayaan diri akhir kurang dari atau sama dengan rata-rata skor kepercayaan diri awal.

$H_{1}: \mu_{b}>\mu_{a}$, Rata-rata skor kepercayaan diri akhir lebih dari rata-rata skor kepercayaan diri awal.

Uji ini dilakukan menggunakan uji Paired Samples Test. Kriteria keputusan yaitu $H_{0}$ ditolak jika signifikansi $<0,05$. Dari hasil pengujian, diperoleh signifikansi $=0.000$. Karena nilai signifikansi $<0,05$, maka $H_{o}$ ditolak dan $H_{1}$ diterima. Hal ini berarti bahwa rata-rata skor kepercayaan diri akhir lebih dari rata-rata skor kepercayaan diri awal.

Kemudian dilanjutkan dengan uji $Z$. Pembelajaran berbasis proyek dikatakan efektif jika proporsi siswa yang telah mencapai skor kepercayaan diri pada kategori minimal baik lebih dari $75 \%$. Adapun hipotesis yang digunakan sebagai berikut.

$H_{0}: \pi \leq 75 \%$, Proporsi siswa yang memperoleh skor kepercayaan diri minimal kategori baik kurang dari atau sama dengan $75 \%$

$H_{1}: \pi>75 \%$, Proporsi siswa yang memperoleh skor kepercayaan diri minimal kategori baik lebih dari $75 \%$

Dari data sampel, diperoleh hasil perhitungan $Z=2,178$ dan karena $Z_{0,05}=1,645$, hal ini berarti $Z>$ $Z_{\alpha}$, sehingga $H_{0}$ ditolak dan $H_{1}$ diterima. Ini berarti bahwa proporsi siswa yang memperoleh skor kepercayaan diri minimal kategori baik lebih dari $75 \%$. Berdasarkan kriteria keefektifan yang ada, maka pembelajaran berbasis proyek efektif ditinjau dari kepercayaan diri siswa.

\section{Pembahasan}

Prestasi belajar, kemampuan berpikir kritis, dan sikap percaya diri merupakan tiga aspek yang penting di dalam pembelajaran matematika. Keterkaitan pembelajaran berbasis proyek dengan prestasi belajar, kemampuan berpikir kritis, dan sikap percaya diri yakni ada pada kegiatan pembelajaran berbasis proyek yang dapat meningkatkan ketiga hal tersebut. Pembelajaran berbasis proyek menggunakan masalah sebagai langkah awal dalam mengumpulkan dan mengintegrasikan pengetahuan baru berdasarkan pengalamannya secara nyata (Hosnan \& Sikumbang, 2014). Oleh karena itu, langkah awal dalam pembelajaran berbasis proyek adalah penentuan tugas proyek. Berkaitan dengan prinsip-prinsip pembelajaran yang dikemukakan oleh Hosnan \& Sikumbang (2014), bahwa tugas proyek yang digunakan adalah yang menekankan pada kegiatan penelitian berdasarkan suatu tema atau topik yang telah ditentukan dalam pembelajaran. Proyek dipandu oleh pertanyaan penyelidikan yang mendorong siswa melakukan penelitian dan memungkinkan siswa untuk menerapkan pengetahuan yang diperoleh (Bell, 2010).

Selain itu proyek yang di rancang dalam penelitian ini berlandaskan pada pendapat Thomas (2000), yakni proyek meliputi tugas yang kompleks, berdasarkan pertanyaan-pertanyaan yang menantang atau sebuah permasalahan, yang melibatkan siswa di dalam desain, pemecahan masalah, pengambilan keputusan atau kegiatan investigasi, siswa diberikan kesempatan untuk bekerja dengan relatif 


\section{Jurnal Riset Pendidikan Matematika, 6 (2), 2019 - 240}

Isnaini Nur Azizah, Djamilah Bondan Widjajanti

waktu yang cukup lama dan berujung pada dihasilkannya produk nyata atau presentasi. Penentuan proyek dengan berlandaskan pada teori yang telah dijelaskan tersebut, dikarenakan menurut pendapat Nitko dan Brookhart (2011) bahwa proyek yang dibuat dengan benar meminta siswa untuk menerapkan dan mengintegrasikan berbagai kemampuan dan pengetahuan. Selain itu, proyek yang baik akan melibatkan siswa dalam berpikir kritis, berpikir reflektif, dan memecahkan masalah.

Pembelajaran berbasis proyek mengacu pada kegiatan siswa dalam merancang, merencanakan, dan melaksanakan proyek yang menghasilkan luaran untuk dipublikasikan seperti produk, publikasi, atau presentasi (Patton, 2012). Pada langkah perancangan langkah-langkah penyelesaian dan penyusunan jadwal proyek, siswa ikut merancang proses yang akan ditempuh dalam mencari solusi dan melakukan penjadwalan terhadap kegiatan yang telah dirancang. Harun (2006, pp. 22-25) menjelaskan bahwa siswa perlu dilibatkan dalam proses perencanaan sehingga siswa merasa bahwa ia memiliki proyek dan berperan aktif dalam menentukan aktivitas.

Pembelajaran berbasis proyek melibatkan siswa dalam kegiatan berkelompok. Tujuan utama dari kelompok proyek adalah sebagai teknik penilaian untuk mengevaluasi apakah siswa dapat bekerja sama secara kooperatif dan tepat untuk menciptakan produk yang berkualitas tinggi (Nitko \& Brookhart, 2011). Manfaat lain yang di dapat siswa dalam pembelajaran berbasis proyek ini adalah meningkatkan kolaborasi peserta didik yang bersifat kelompok (Hosnan \& Sikumbang, 2014).

Efekttifnya pembelajaran berbasis proyek ditinjau dari prestasi belajar, kemampuan berpikir kritis dan sikap percaya diri siswa, dikarenakan pada pembelajaran berbasis proyek siswa terlibat aktif dalam mengkonstruk pengetahuannya sendiri sehingga kegiatan belajar berpusat pada siswa dan pembelajaran menjadi lebih bermakna. Hal ini sesuai dengan pendapat Stivers (2010) bahwa pembelajaran berbasis proyek mengajarkan siswa bukan hanya konten, tetapi juga keterampilan. Keterampilan ini meliputi komunikasi dan kemampuan presentasi, organisasi dan keterampilan manajemen waktu, keterampilan penelitian dan penyelidikan, penilaian diri dan kemampuan refleksi, partisipasi kelompok dan keterampilan kepemimpinan, dan berpikir kritis. Dengan demikian siswa dapat mengkonstruk dan membangun pengetahuan mereka sendiri serta menyimpan lebih banyak informasi ketika mereka belajar dengan melakukan (Bell, 2010).

Pembelajaran berbasis proyek juga efektif ditinjau dari kemampuan berpikir kritis siswa. Hal ini dikarenakan terdapat langkah pembelajaran berbasis proyek yang dapat melatih kemampuan berpikir kritis siswa. Pada langkah perancangan penyelesaian langkah-langkah proyek, siswa berusaha untuk merancang proses yang akan ditempuh dalam mencari solusi serta berusaha memecahkan sebuah permasalahan dan tantangan yang kemudian diarahkan dalam membuat keputusan sendiri, sehingga pada kegiatan ini siswa dilatih menggunakan kemampuan berpikir kritisnya. Selain itu, pada LKS berbasis proyek terdapat latihan soal berpikir kritis yang mendorong siswa untuk mencari solusi dari permasalahan yang diberikan.

Hal tersebut didukung kajian teoritis yang diungkapkan oleh Hosnan dan Sikumbang (2014), bahwa pembelajaran berbasis proyek mendorong siswa dalam berpikir kritis, memecahkan masalah, berkolaborasi, serta mencoba berbagai macam bentuk komunikasi, hal ini dikarenakan selama pembelajaran siswa berusaha memecahkan sebuah permasalahan atau tantangan yang tidak memiliki satu jawab pasti, selain itu siswa juga mengambil keputusan sendiri dalam kerangka kerja yang telah ditentukan bersama sebelumnya. Berkaitan dengan proses membuat keputusan/pengambilan keputusan, Santrock (2010) mengemukakan bahwa dalam pengambilan keputusan melibatkan proses berpikir, dimana individu mengevaluasi alternatif-alternatif dan membuat pilihan.

Kegiatan siswa dalam menyimpulkan terhadap suatu hasil yang telah diperolehnya dalam proyek merupakan kemampuan siswa dalam berpikir kritis. Menurut Van Gelder dan Willingham (Eggen \& Kauchak, 2011) bahwa dalam berpikir kritis mencakup kemampuan dan kecenderungan individu untuk membuat dan menilai kesimpulan berdasarkan bukti. Hal ini dikarenakan dalam berpikir kritis menuntut penggunaan keterampilan kognitif yang secara strategis sesuai dengan situasi tertentu, dan juga merupakan kontrol aktif dari proses berpikir diri untuk membuat kesimpulan yang baik ( $\mathrm{Ku} \& \mathrm{Ho}, 2010)$.

Ditinjau dari kepercayaan diri siswa, pembelajaran berbasis proyek juga terbukti efektif. Hal ini dikarenakan dalam pembelajaran berbasis proyek terdapat kegiatan diskusi dan kegiatan mempresentasikan hasil proyek/produk. Kegiatan ini dapat melatih siswa dalam meningkatkan kepercayaan dirinya, karena siswa berlatih untuk terlihat tenang dan tidak memiliki rasa takut ketika berhadapan dengan orang banyak serta melatih siswa bertanggung jawab terhadap proyek yang telah dikerjakan. Siswa dilatih untuk yakin terhadap kemampuan yang dimiliknya dalam menyampaikan ide-idenya ketika diskusi dan 
mengembangkannya menjadi sebuah produk sehingga siswa dapat bersikap optimis terhadap produk yang ditampilkannya. Seseorang yang percaya bahwa dirinya dapat memproduksi hasil, mencapai tujuan, atau melakukan tugas dengan kompeten menunjukkan bahwa dirinya memiliki kepercayaan diri (Schunk, 2012). Selain itu keyakinan terhadap kemampuan diri, optimis dan bertanggung jawab merupakan hal yang menunjang siswa dalam meningkatkan kepercayaan diri. Hal senada juga diungkapkan oleh Lauster (Ghufron \& Suminta, 2010), bahwa keyakinan terhadap kemampuan diri, optimis dan bertanggung jawab merupakan aspek-aspek dalam kepercayaan diri.

Pembelajaran berbasis proyek juga efektif ditinjau dari prestasi belajar. Hal ini dikarenakan terdapat langkah pembelajaran berbasis proyek yang dapat memfasilitasi siswa dalam memahami materi. Pada langkah penyelesaian proyek, informasi yang telah siswa dapatkan selama kegiatan pembelajaran dapat diterapkan siswa untuk menganalisis dan mengkaji proyek yang telah dilakukan. Hal ini senada dengan pendapat Garber (2009) bahwa prestasi mengacu pada keberhasilan individu dalam memperoleh informasi, terutama berkenaan dengan kemajuan akademis. Selain itu, pada lembar kerja siswa (LKS) telah disediakan kegiatan-kegiatan untuk siswa dalam memahami materi dan mengolah informasi. Hal ini tentunya membawa dampak yang positif terhadap prestasi belajar siswa.

Pada akhir pembelajaran, siswa diberi kesempatan untuk mengungkapkan pengalamannya baik itu kesulitan atau kendala selama mengerjakan proyek. Hal ini tentunya membuat siswa untuk terus berusaha memperbaiki produk agar menjadi lebih baik lagi. Selain itu, guru melakukan refleksi tentang pembelajaran yang telah dilakukan dengan mengajukan beberapa pertanyaan seperti apakah pembelajaran berbasis proyek menyenangkan, apa yang membuat kalian tertarik pada pembelajaran ini, dan apa yang mengesankan dalam membuat tugas proyek, dan sebagainya. Kegiatan ini dapat memberikan dampak yang positif pula terhadap kepercayaan diri siswa.

Hasil penelitian ini mendukung penelitian sebelumnya yang dilakukan oleh Imawan (2015) bahwa pembelajaran berbasis proyek efektif ditinjau dari prestasi belajar, kemampuan berpikir kritis dan sikap percaya diri siswa. Dengan demikian pembelajaran berbasis proyek terbukti efektif meningkatkan prestasi belajar siswa, kemampuan berpikir kritis, dan sikap percaya diri siswa. Kemudian hasil hasil penelitian Ismail (2018) juga menunjukkan bahwa pembelajaran berbasis proyek tidak hanya efektif untuk meningkatkan kemampuan berpikir tingkat tinggi siswa tetapi juga mempengaruhi aspek sikap yaitu kepercayaan diri.

\section{SIMPULAN}

Berdasarkan hasil penelitian dan pembahasan diperoleh kesimpulan bahwa pembelajaran berbasis proyek pada materi statistika efektif ditinjau dari prestasi belajar, kemampuan berpikir kritis, dan kepercayaan diri untuk siswa SMP kelas VII. Dengan demikian, pembelajaran berbasis proyek direkomendasikan untuk dapat diterapkan dalam pembelajaran matematika pada jenjang SMP. Berdasarkan temuan penelitian, peneliti menyarankan bagi para guru untuk dapat menerapkan pembelajaran berbasis proyek sebagai sarana untuk meningkatkan prestasi belajar, kemampuan berpikir kritis, dan kepercayaan diri siswa, baik pada jenjang SMP maupun SMA. Beberapa hal menjadi keterbatasan dalam penelitian ini, di antaranya popuasi dan sampel yang digunakan masih terbatas serta analisis data yang dilakukan masih menggunakan statistik univariat. Untuk itu disarankan kepada peneliti lainnya untuk dapat menyelidiki kembali efektivitas pembelajaran berbasis proyek dengan melibatkan populasi dan sampel yang lebih luas, sehingga memungkinkan generalisasi yang lebih luas pula. Selain itu, analisis data yang lebih mendalam perlu dilakukan, baik menggunakan pendekatan kuantitatif (misalnya menggunakan statistik multivariat) maupun pendekatan kualitatif.

\section{DAFTAR PUSTAKA}

Arends, R. I., \& Kilcher, A. R. (2010). Teaching for student learning: Becoming an accomplished teacher. In Routledge. Taylor \& Francis e-Library. https://doi.org/10.4324/9780203866771

Badan Penelitian dan Pengembangan. (2013). Laporan hasil Ujian Nasional tahun 2012/2013. Badan Penelitian dan Pengembangan Pendidikan, Kementerian Pendidikan dan Kebudayaan.

Badan Penelitian dan Pengembangan. (2014). Laporan hasil Ujian Nasional tahun 2013/2014. Badan Penelitian dan Pengembangan Pendidikan, Kementerian Pendidikan dan Kebudayaan.

Badan Penelitian dan Pengembangan. (2015). Laporan hasil Ujian Nasional tahun 2014/2015. Badan 
Penelitian dan Pengembangan Pendidikan, Kementerian Pendidikan dan Kebudayaan.

Badan Penelitian dan Pengembangan. (2016). Laporan hasil Ujian Nasional tahun 2015/2016. Badan Penelitian dan Pengembangan Pendidikan, Kementerian Pendidikan dan Kebudayaan.

Bell, S. (2010). Project-based learning for the 21st century: Skills for the future. The Clearing House: A Journal of Educational Strategies, Issues and Ideas, 83(2), 39-43. https://doi.org/10.1080/00098650903505415

Bender, W. N. (2012). Project-based learning: Differentiating instruction for the 21st century. Corwin Press.

Casner-Lotto, J., \& Barrington, L. (2006). Are they really ready to work? Employers' perspectives on the basic knowledge and applied skills of new entrants to the 21st century US workforce. Partnership for 21st Century Skills.

Chrissanti, M. I., \& Widjajanti, D. B. (2015). Keefektifan pendekatan metakognitif ditinjau dari prestasi belajar, kemampuan berpikir kritis, dan minat belajar matematika. Jurnal Riset Pendidikan Matematika, 2(1), 51. https://doi.org/10.21831/jrpm.v2i1.7150

Duron, R., Limbach, B., \& Waugh, W. (2006). Critical thinking framework for any discipline. International Journal of Teaching and Learning in Higher Education, 17(2), 160-166. https://doi.org/10.1016/j.nepr.2006.09.004

Ebel, R. L., \& Frisbie, D. A. (1991). Essentials of educational measurement. Prentice Hall.

Eggen, P., \& Kauchak, D. (2011). Strategies and models for teachers: Teaching content and thinking skills. Pearson Higher Ed.

Fisher, A. (2001). Critical thinking: An introduction. Cambridge University Press.

Garber, B. D. (2009). Developmental psychology for family law professionals: Theory, application and the best interests of the child. Springer Publishing Company.

Ghufron, M. N., \& Suminta, R. R. (2010). Teori-teori psikologi. Ar-Ruzz Media.

Harun, Y. bin. (2006). Project-based learning. educating the millennial learner. Educational Technology Division Ministry of Education.

Hosnan, M., \& Sikumbang, R. (2014). Pendekatan saintifik dan kontekstual dalam pembelajaran abad 21: Kunci sukses implementasi kurikulum 2013. Ghalia Indonesia.

Imawan, O. R. (2015). Perbandingan antara keefektifan model guided discovery learning dan projectbased learning pada matakuliah geometri. PYTHAGORAS: Jurnal Pendidikan Matematika, 10(2), 179. https://doi.org/10.21831/pg.v10i2.9156

Ismail, R. (2018). Perbandingan keefektifan pembelajaran berbasis proyek dan pembelajaran berbasis masalah ditinjau dari ketercapaian tujuan pembelajaran. Pythagoras: Jurnal Pendidikan Matematika, 13(2), 181-188. https://doi.org/10.21831/pg.v13i2.23595

Keller, M. M., Neumann, K., \& Fischer, H. E. (2017). The impact of physics teachers' pedagogical content knowledge and motivation on students' achievement and interest. Journal of Research in Science Teaching, 54(5), 586-614. https://doi.org/10.1002/tea.21378

Klein, J. I., Taveras, S., King, S. H., Commitante, A., Curtis-Bey, L., \& Stripling, B. (2009). Projectbased learning: Inspiring middle school students to engage in deep and active learning. NYC Department of Education.

Kpolovie, P. J., Joe, A. I., \& Okoto, T. (2014). Academic achievement prediction: Role of interest in learning and attitude towards school. International Journal of Humanities Social Sciences and Education (IJHSSE), 1(11), 73-100. https://www.arcjournals.org/pdfs/ijhsse/v1-i11/10.pdf

Ku, K. Y. L., \& Ho, I. T. (2010). Metacognitive strategies that enhance critical thinking. Metacognition and Learning, 5(3), 251-267. https://doi.org/10.1007/s11409-010-9060-6

Lang, H. R., \& Evans, D. N. (2006). Models, strategies, and methods for effective teaching. Allyn \& Bacon.

Peraturan Menteri Pendidikan dan Kebudayaan Nomor 22 tahun 2016 tentang standar proses pendidikan dasar dan menengah, (2016).

Peraturan Menteri Pendidikan Nasional Republik Indonesia Nomor 22 Tahun 2006 tentang standar isi 
untuk satuan pendidikan dasar dan menengah, Pub. L. No. 22, Peraturan Menteri (2006).

Merilia, S., Fajaruddin, S., \& Arbain, A. (2019). An assessment of an English textbook of vocational school. Arisen: Assessment and Research on Education, 1(2). https://doi.org/10.33292/arisen.v1i2.46

Miller, M. D., Linn, R. L., Gronlund, N. E., \& Linn, R. L. (2008). Measurement and assessment in teaching (10 Edition). Pearson.

Moore, K. D. (2014). Effective instructional strategies: From theory to practice. Sage Publications.

Nitko, A. J., \& Brookhart, S. M. (2011). Educational assessment of students. Pearson/Allyn \& Bacon.

Patton, A. (2012). Work that matters the teacher's guide to project-based learning. Paul Hamlyn Foundation.

Paul, R., \& Elder, L. (2019). The miniature guide to critical thinking concepts and tools. Rowman \& Littlefield.

Peter, E. E. (2012). Critical thinking: Essence for teaching mathematics and mathematics problem solving skills. African Journal of Mathematics and Computer Science Research, 5(3). https://doi.org/10.5897/AJMCSR11.161

Undang-Undang Republik Indonesia nomor 20 tahun 2003 tentang sistem pendidikan nasional, Pub. L. No. 20, Undang-Undang Republik Indonesia 26 (2003).

Preston, D. L. (2005). 365 steps to self-confidence. How To Books.

Rahmadhani, E. (2018). Model pembelajaran process oriented guided inquiry learning (POGIL): Peningkatan disposisi matematika dan self-confidence mahasiswa tadris matematika. Jurnal Riset Pendidikan Matematika, 5(2), 159-167. https://doi.org/10.21831/jrpm.v0i0.20962

Ramadhani, R. (2018). The enhancement of mathematical problem solving ability and self-confidence of students through problem based learning. Jurnal Riset Pendidikan Matematika, 5(1), 127. https://doi.org/10.21831/jrpm.v5i1.13269

Santrock, J. (2010). Educational psychology. In Handbook of Educational Psychology. https://doi.org/10.1146/annurev.ps.05.020154.002041

Schunk, D. H. (2012). Learning theories: An educational perspective. Pearson.

Singh, T., \& Kaur, P. (2008). Effect of meditation on self confidence of student-teachers in relation to gender and religion. Journal of Exercise Science and Physiotherapy, 4(1), 35. http://www.efha.in/wp-content/uploads/2015/01/JESP-4-35.pdf

Stacey, K. (2011). The PISA view of mathematical literacy in Indonesia. Journal on Mathematics Education, 2(2). https://doi.org/10.22342/jme.2.2.746.95-126

Stivers, J. (2010). Project based learning: A dynamic approach to teaching in which students explore real-world problems and challenges, simultaneously developing 21 st century skills while working in small collaborative groups. Educational Psychology. http://www.fsmilitary.org/pdf/Project_Based_Learning.pdf

Thomas, J. W. (2000). A review of research on project-based learning. The Autodesk Foundation. https:/tecfa.unige.ch/proj/eteach-net/Thomas_researchreview_PBL.pdf

Tim Pengembang MKDP Kurikulum dan Pembelajaran. (2011). Kurikulum \& pembelajaran. Rajawali Pers. 